\title{
Alienation of the African Scholar in the Global Academia as a Challenge to Securing a Developed Africa
}

\author{
Stephen Oladele Ayankeye* \\ Professor of Pastoral Care, Counselling and Deputy President Academincs at The Nigerian Baptist Theological Seminary, P.M.B. 4008, Ogbomoso, \\ Oyo State, Nigeria
}

\section{*Corresponding Author \\ Stephen Oladele Ayankeye}

\section{Article History}

Received: 02.08.2019

Accepted: 19.08.2019

Published: 30.08 .2019

\begin{abstract}
One of the subtle ways of hindering the possibility of securing a united and developed Africa is to relegate the African scholar to the background in the global academia. There are some evidences indicating the fact that the African scholar has not being able to contribute to the development of his/her continent because of some alienating strategies in the areas of power control and publishing/promotion. It is however, regrettable that the alienating experience of the African scholar is two-dimensional. There is the external dimension in which case the Euro-western world continues to dominate the terrain of academia. The internal dimension appears to be worse because it is self-imposed through adoption of academic curricula foreign to the African context. This paper therefore, advocates that the African Scholar should intentionally intensify his/her participation in the global academia in a way that will contribute to securing a united and developed Africa.
\end{abstract}

Keywords: Scholar, Alienation, Academia, Africa.

\section{INTRODUCTION}

A popular saying is that the world has become a global village. If this is true, it is expected that every person within that village will be treated as a bonafide member who can participate in the affairs of the community without fear or favour. In other words, none in the global village is expected to be playing a second fiddle. Regrettably, the case is not as described here when it comes to the global academia. This is because the African scholar is an alienated self in the academia which puts question mark on the globalization bid. This is not without enough evidences that there is global conspiracy designed and supported by the African scholar to marginalize him/her in the global intellectualism. Without mincing words, one is convinced that the African scholar is an alienated self in the academia.

For the sake of clarity, a few terms are hereby explained. To start with, Alienation is a psychological term that carries with it psychic pains. It goes along with psychological ostracization that can easily throw its victim off emotional balance and lead to psychological dysfunctioning. Alienation is a crisis because it throws a serious challenge to the affected person. Also, crisis by definitionis homeostatic imbalance in life stance which affects the functioning ability of the person concerned negatively [1]. Practical psychology hereby refers to a counselling approach to examining an existential issue. In other words, the difficulty being encountered by the African scholar in the global academic arena is being analyzed from a counselling psychological stand point with the hope of stirring up the African scholar to be African and still compete favourably in the global academia as he/she recognizes the dimensions of the alienation bid and addresses same objectively. African scholar operationally defined is descriptive of an African academic who has to face the challenge of marginalization in the global academia.

This paper therefore, dissects the two main dimensions of the alienation of the African scholar and makes some recommendations that can help the African scholar appreciate the positive contributions of the Western world to the development of education in Africa, recognize the negative side and make effort to stand tall in the global knowledge community. Methodologically, the paper employs content analysis to establish the fact that scholastic alienation is a tragedy. The dimensions of the alienation are presented as fair as practicable. A conclusion is then drawn with recommendations to beam searchlight into the academic future of the African scholarship where egalitarianism should be exemplified at home and abroad.

Copyright @ 2019: This is an open-access article distributed under the terms of the Creative Commons Attribution license which permits unrestricted use, distribution, and reproduction in any medium for non commercial use (NonCommercial, or CC-BY-NC) provided the original author and source are credited. 


\section{Dimensions of the alienation}

The scholastic alienation being experienced by the African scholar rears its ugly head in two dimensions which are hereby classified as external and internal alienation. Each of these is discussed distinctly.

\section{External dimension of the alienation}

It has been indicated in the introduction that the alienation of the African scholar in the academia is a reality. The basis of this assertion is that strategies are put in place by non-Africans for the intellectual ostracization. It is necessary to appeal to the central argument of Mlambo in his paper titled: "Western Social Sciences and Africa: The Domination and Marginalization of a Continent [2]" argued that,

apart from other effects, Western science, capitalism and social science and other knowledges and practices not only led to the domination of the African continent by the West but also to its marginalization in the world in terms of economic development and Africa's capacity to participate fully in the global knowledge community (Mlambo, "Western Social Sciences and Africa: The Domination and Marginalization of a Continent"

(www.codespia.org/IMG/pdf/Alois_S_Mlambo.pdf)[3].

This, according to Yankah, manifests in the aspects of power base, politics of mainstream, language, editorial segregation and cultural issues [4].

\section{Regarding Power Base}

Yankah succinctly carried out an x-ray of the experience of the African scholar in the educational terrain and academia to showcase the external strategies for suffocation. Yankah arrived at the striking conclusion as he laid emphasis on the need for reexamining the global history with a focus on the place of knowledge in human development. He further noted that level of advancement is clearly dependent upon "the construction of knowledge, access to knowledge, the transfer of knowledge, and the application of knowledge [5]". Each society is considered worthy of being impacted by application of knowledge, which should be the concern of scholarship targeted toward developing human life. In other words, the relevance of education lies in being pragmatically oriented by meeting the needs of humans in the society.

The secret of external dimension of scholastic alienation of the African intellectual lies in the lopsided globalization bid. According to Yankah, "these issues become compounded by the concept of globalization, which in a sense drives the world towards a culture of uniformity, but in reality becomes a euphemism for transnational domination [6]". The import of Yankah's expressed opinion here is that, the current globalization concept majorly opens the protective fences of the developing countries to the domination of the so-called euro-western big brothers or sisters.

One of the key issues ensuing from the above scenario explained by Yankah is the alienating style of education. The African scholar unavoidable finds him/herself in educational and knowledge production systems that make him/her a double-loser in the global market. This is the situation where such a scholar is trained in the western form of education but is still considered incompetent by the western world to have acclimatized with the western academic trends [7]

The picture of the experience of the western educated African academic is depicted in Adogame's discussion of the insider/outsider paradigm in religious adherence. Adogame asserted thus:

The negotiation and navigation of boundaries is usually a very delicate and controversial venture because it often has cultural, religious, political and other undertones. The Insider or Outsider positions are much complicated than they may appear due to their attendant tendency towards inclusivity and exclusivity [8].

The cultural and political undertones which render the African scholar an alienated self in the global academia are critical. The experience is critical because it is only understood by the western educated African after negotiating and navigating across his/her cultural boundaries to put on academic skin of another cultural orientation.

A good analogy of the painful experience of the African scholar in the apparent academic globalization bid is the experience shared by Amenga-Etego during a field study. The down to-earth researcher likened herself to a diviner with his divinatory items in her interactive activities with her Nankani religio-cultural people of Northern Ghana. This was the situation whereby the assiduous researcher would unpack and repack the content of her bag each time she met with her informants. According to her,

The content of the bag which included pencils, pens, notepads, a camera, tape recorder, batteries and cassettes and the entire process of my research endeavour found its contextual understanding in the initiation process of the ... Nankani diviner in search of his divinatory items [9] 
In other words, the western trained African scholar is only made to know that he/she is not absorbable into the esteemed position in the western academia after having gone through the same rigours with the western students. Like Amenga-Etego, the African scholar would have loaded and offloaded his/her "diviner's bag" taken from Africa to the west in the course of study, thinking that there is true globalization in the academia that could afford him/her job opportunity in a choice part of the globe. It would be to his/her amazement that he/she is made to realize that he/she does not have a place to serve because that is not where he/she belongs.

Furthermore, due to the issue of power base, African indigenous systems of knowledge production are not regarded as authentic and are described as 'primitive'. Regrettably, the same or similar sources in the western part of the globe are considered as legitimate and reliable. This is a stylistic way of keeping African intellectual materials at bay while the western ones are given prominence. It is not funny that a western scholar can climb the academic ladder and become a professor in the history of an African country without having visited the country. Yet, his research is considered valid in the academia but an African author who documents his/her work on an issue in Africa is viewed with suspicion [10]. Indeed, this is one of the major reasons why literature is lacking on Africa, except the ones written on Africa by the western authors.

Again, orality was for long not recognized as a reliable source of academic information. The resultant effect of the game of non-recognition of the native African source of information is further derobing the African scholar of his/her grip on the familiar terrain of source of knowledge. The case is that the western agencies define and control Africa's reality and perspectives. When this is done, the west keeps monopolizing authority, rendering the academic centre confined in a way that the African scholar in particular, is excluded from global academic discourse [11]. For instance, Africans and African Americans sought admission into higher education in the 1800s and early 1900s in America's Flagship State universities but were only admitted for Ph.D in the 1960s[12]. The foregoing are only prelude to further discrimination against African intellectuals as evident in the next point focusing on systematized intellectual master-slave relationship.

\section{Regarding Politics of Control}

The dictum, "He who pays the piper dictates the tune" is a reality in the globalization bid in the academia. Alienating strategies which push the African scholar to the background is the perpetual central place in international academic discourse which is painted as the birthright of the euro-western extraction. The scenario in the politics of the academia is that the euro-western extraction is believed to be the originator of international academic discourse and publishing. It is then believed that the right to exert the weight of the western zone's cultural tenets should be accorded it. These results in the usurpation of the control of academic authority tyrannically and thereby rendering African intellectuals and their academic programmes ostracized in the academia [13].

Additionally, the African scholar is faced with the challenge of non-recognition because of the language community into which he/she was born. Historically, the English, French and German were the cultures of scholarship within modernity. This is further elaborated that from 1850 to 1945 , a minimum of 95 percent scholars and scholarship came into limelight through the medium of English, French, German, Italian and Spanish. The countries which languages were employed thereby gained prominence in the academia; and these languages must be studied to understand global operations [14]. The situation was so devastating for the African intellectuals and others in their category that it appeared knowledge acquisition was impossible for them.

The observation made by Yankah is noteworthy. As scholarship cultures shifted gradually to the United States of America (USA) from 1945, USA became the academic central market where all and sundry must visit for recognition. The way USA, in particular has held to the handling of academic whip which can be used as and when desired, by the western world, the status quo might not have been so maintained for long if the grip of control was elsewhere[15]. The alienation was noted and protested as far back as 1969. Little wonder why "African and African American scholar-activists staged protests and disrupted panels at the African Studies Association (ASA) conference in Montreal, demanding fundamental structural change in the organization to reverse over two decades white domination of the field of African Studies[16]. For instance, if Nigeria, Ghana and other African countries were in control from the initial time, the monopoly of control of the academia would have been challenged. The case would have been like the proverbial call by a king for rotational chairmanship among the kings in a part of an African country only after losing the position he held onto for many years.

Another aspect of the western bid to hold on to unchallenged control in the academy internationally reflects in the publishing activities. This is the situation where success in the bid to share intellectual materials by the African scholar through publishing is politicized. Though he contended the stand to some extent, Zell cited Bgoya to have noted that "the predominant attitude of the Europian and American book trades from buyers to booksellers to Liberians is at best to disregard African intellectuals' input and at worst to deny any place in international knowledge production to Africa and the Africans [17]." The African scholar needs to find favour in the sight of the western big brothers whose shoulders must be climbed in order to gain the favour of international publishing houses. The African writer is usually made to use only the language or terminologies favoured by his/her academic benefactors - whether or not in the process the writer's initial focus for writing is thwarted [18]. 
Evidently, the scenario points to a colonial approach where the African intellectual is considered incapable of meeting the global academic discourse. Has the west-colonialist changed his perception of Africans who he classified with apes in the era of slavery? The answer to this question is left with the African writer who is not free to decide on the extent to which he/she can deploy the language of his/her context in his/her manuscript meant for publishing. The alienating experience of the African scholar in the academia is apparently another phase of colonization of Africa in the name of globalization. Indeed, "globalization is merely the promotion of another local culture and knowledge to the world stage [19]." It is in order to keep the knowledges of the power-that-be dominant that other knowledges are rendered to the background [20].

Indeed, it is not gainsaying that the African scholar has found himself victim rather than victor in the global scene of the academia, as it were. The reason is that he/she is bereft of his/her cultural identity in a globalized academia that gives little or no recognition to cultural particularities, especially when it is not the western culture. The experience is psychologically traumatizing. The picture is clearly captured by Amenga-Etego in her discussion on international development and policies on religious matters. According to her.

Over the years, issues of culture, gender, participation and sustainability have become topical and strategic to the concerns of development. Although these inclusive approaches are essential in today's global world, they continue to present new problems in terms of cultural particularities. Hence, despite the constant search for innovative policies at the international levels, there are great difficulties in their implementations in particular contexts. This is not just an issue of religious cultural differences, very often, what is asked for and what is supplied or the conditions under which such supplies are given are not harmonious [21].

The harmony expected to be derived from globalization in the academia, in particular has not surfaced. While attention is directed toward building the Euro-western culture, the African intellectual finds none to protect and propagate his/her own culture and ideals academically.

Thus far, much has been stated on the external dimension of the alienation of the African scholar in the academia. The points of control and inward-looking approach employed by the western world in the globalization bid that renders the African intellectual incapacitated has not exonerated the African scholar. The reason is that, as rightly noted by Awoonor, the African scholar also enthusiastically collaborates with the imperial academic and publishing houses to marginalize him/her "to the Ghetto of global intellectualism [22]". Some of the ways by which this is done are hereby presented as internal dimension of the alienation.

\section{Internal dimension of the alienation}

It is worthy of note that blaming the alienation of the African scholar totally on the western imperialist will not be fair. There are enough indications that the opportunities to get liberated by the African intellectual from enslavement in the global academy are not adequately seized. A few of the internal dimension of the alienation in the academia are highlighted here.

\section{Regarding Academic Curricula}

One of the internal dimensions of alienation of the African scholar in the academy is the formal educational system borrowed from the west. It is in the regulatory approach to learning that the African scholar prides him/herself, even when it does not benefit the African soil much. This is not to say that the western educational system did not add value to the intellectual foundation of Africa. The problem is that consideration was not given enough to the African cultural milieu to accommodate the traditional sources of knowledge [22].

Also, while one is not unaware of limitations of finance and some other relevant resources, the description of the complacent attitude of the African leadership by Awoonor is a captivating one. To him,

The tragic circumstances in which African Universities find themselves today are partially self-inflicted. Myopic leadership and a mindless addiction to intellectual subservience are some of the glaring reasons why fifty years, Africa's higher institutions of learning remain stagnated and in some tragic cases have totally become irrelevant [23].

The description above is anchored on the problems of poor financial base and low innovative proves which reflect in the syllabi operated for years.

Concerning the above assertion on the issue of education, the national education policies of many African countries are still tied to the western educational style alien to the African context. Materials from the west are idolized to the point that they are adopted hook line and sinca, even when they are alien to the African context. The African scholar cannot blame the euro-western educational imperialists in this case, because contextualizing the materials lies within the confine of the African user. So, wholesale application of western knowledge production in the bid to remain an acceptable member of the academic global village is the doing of the African intellectual [24]. 


\section{Regarding Academic Promotional Process}

Again, it is regrettable to note the heart-renting approach to academic promotion employed in the tertiary academic institutions in Africa. While the African scholar faces the challenge of marginalization of research and lack of mentoring in the promotional and tenuring process, academic bullying is also found in Africa [25]. The ugly scenario is the case "where the candidate's work on Africa is subjected to external assessment, sometimes in Europe and America [26]." This is a ridiculous situation where a Euro-American will assess the work done on Africa by an African and the former will determine whether or not what the latter has done is good. The issue remains that the assessor has to apply his own foreign standard to judge the African's work on Africa, and that soothens the heart of the African being examined by a westerner than when he/she is assessed by his/her African academic brothers and sisters.

\section{Regarding Participation in Academic Research on Africa}

Linked to the foreign assessment is the occasion where African subjects him/herself to the use of Western scholars as field informant. The information supplied by the African informant is considered authentic in the scholarly work produced by the western author on Africa [27]. The regrettable aspect of the experience is that the same information, if documented by the African informant, may be treated with contempt by the western lords in the academy. It is even nauseating to note that the western informee may choose whether or not he/she will acknowledge the informant in the work. The funny way of showing appreciation to the informant may be through invitation for a meal. By this, the African will feel highly honoured while he or she is derobed of his intellectual birthright, without resistance. This is the case where the cultural insider is tactically locked out of prominence by his or her own volition, instead of at least, striving for complementarity in the academic relationship [28].

The African's self-ostracizing attitude also reflects in his/her giving preference to western sources to authenticate his/her work on Africa. The research carried out on Africa is easily pushed aside while African scholar is searching for resources. This quite negates a popular saying in the southwestern Nigeria, viz: Omo eni ko nii se idi bebere ki a ko lekesi idi omo elomiran (literally meaning, one's daughter cannot have big buttocks and you go and decorate another person's daughter's buttocks with beads). The actual meaning in this context is that one should not be promoting the culture of another person at the expense of one's own culture. The situation in Africa however, indicates that the African intellectual collaborates in the bid to keep him/her at bay in the global academy.

\section{CONCLUSION AND RECOMMENDATIONS}

The position of the African scholar in the global academic scene has been examined. It is clear that the African scholar is an alienated self in the global academia. The excruciating treatment being experienced by the African scholar is found to be two dimensional. The euro-western powers in the intellectual market are demonstrating what may be described as second phase of colonization. This is reflected in the areas of decisions on who is to determine the quality of the knowledge production of Africans for publication. The external dimension of the marginalization also include not considering a western trained African qualify to practice in the west without contemptuous treatment.

The above external intellectual slap notwithstanding, the African scholar has collaborated in various ways to play the second fiddle. One of the ways the self-denigrating experience occurs is in the enslaving curricula for schools in Africa with little or no consideration for the cultural context. Another self-marginalizing step is the promotional agenda for the African scholar that must be subjected to the western style hook line and sinca. The alienating experiences notwithstanding, a step forward is needed because having been colonized in one way or the other is not enough for African scholar to remain an academic slave [29]. It is believed that the African scholar should participate in the globalization in the academy by attending international conferences and participating actively in order to learn and understand global academic trend. This should not however, be done to jettison the fact that Africans are full human beings whose colour should not be used to get them marginalized. Participation in the global academy should not be geared toward upholding the cultures of a group but all and sundry's particular cultures should be valued. Experiences from global meetings should be adapted to suit the African situation. African authors need to take up the challenge of writing on contemporary issues that affect Africa. African writers should be thorough in the process of carrying out research and reporting same in a way that standard will not be compromised. Existing publishing houses in Africa should be standardized to meet global taste and new ones be encouraged to enhance availability of published African literature.

More importantly, the African scholar will continually experience self-actualization academically if educational planning for Africa takes the rich African cultural context into account. Academic institutions in Africa need to always link with industries to find out the type of labour required in order to align the academic curricula to meet such personnel needs. The linkage will make tertiary institutional education relevant to the African situation. In other words, there should be consideration for the services required by industries in the process of designing, implementing and evaluating educational curricula. The crisis of alienation being experienced by the African scholar will reduce drastically if the intent of this paper is considered favourably by relevant stakeholders in the acacdemia in Africa. 


\section{REFFRENCE}

1. Pavelsky R. L. (2005). "Crisis Intervention Theory." Dictionary of Pastoral Care and Counselling, R. J. Hunter, Ed. (Nashville: Abingdon Press, 245.

2. Alois, Mlambo, Ed. (2013). "The Domination and Marginalization of a Continent" www.codesria.org//MG/pdf/Alois s-Mlambo.pdf. Accessed 20/7/2013.

3. Mlambo.(2013). "The Domination and Marginalization of a Continent" www.codesria.org/IMG/pdf /Alois s-Mlambo.pdf. Accessed 20/7/2013.

4. Kwesi Yankah, Globalization and the African Scholar (Legon, Accra: Faculty of Arts, University of Ghana, 2004), 2-11.

5. Yankah, Globalization and the African Scholar, 11.

6. Yankah, 1.

7. Yankah, 11.

8. Adogame, A. (2005). To be or not to be? Politics of Belonging and African Christian Communities in Germany. Bayreuth african studies series, 75, 95.

9. Amenga-Etego, R. M. (2011). Mending the broken pieces: Indigenous religion and sustainable rural development in northern Ghana. Africa World Press.

10. Yankah, K. (2004). Globalization and the African scholar. Faculty of Arts, University of Ghana.

11. Yankah, K. (2004). Globalization and the African scholar. Faculty of Arts, University of Ghana.

12. Evans, S. Y. (2007). Women of color in American higher education. Thought \& Action, 23, 131-138.

13. Yankah, 3 .

14. Mignolo, W. D. (1998). Globalization, civilization processes, and the relocation of languages and cultures. The cultures of globalization, 32-53.

15. Yankah, K. (2004). Globalization and the African scholar. Faculty of Arts, University of Ghana.

16. Gershenhorn, J. (2009). " Not an academic affair": African American scholars and the development of African Studies programs in the United States, 1942-1960. The Journal of African American History, 94(1), 44-68.

17. Zell, H. M. (2013). Print vs. electronic, and the 'digital revolution' in Africa. The African Book Publishing Record, 39(1), 1-19.

18. Yankah, K. (2004). Globalization and the African scholar. Faculty of Arts, University of Ghana.

19. Foucault, M. (1980). Power/knowledge: Selected interviews and other writings, 1972-1977. Vintage.

20. Amenga-Etego, R. M. (2011). Mending the broken pieces: Indigenous religion and sustainable rural development in northern Ghana. Africa World Press.

21. Yankah, K. (2004). Globalization and the African scholar. Faculty of Arts, University of Ghana.

22. Yankah, K. (1999). African folk and the challenges of a global lore. Africa Today, 9-27.

23. Awoonor, K. (1975). The breast of the earth: A survey of the history, culture, and literature of Africa south of the Sahara. Garden City, N. Y: Anchor Press.

24. Yankah, K. (2004). Globalization and the African scholar. Faculty of Arts, University of Ghana.

25. Frazier, K. N. (2011). Academic Bullying: A Barrier to Tenure and Promotion for African-American Faculty. Florida Journal of Educational Administration \& Policy, 5(1), 1-13.

26. Yankah, K. (2004). Scholarly Authority and the Quest for a New World Academic Order1. Journal of Culture and Its Transmission in the African World, 1(2), 1.

27. Yankah, K. (2004). Globalization and the African scholar. Faculty of Arts, University of Ghana.

28. Chitando, E. (2005). The Insider/Outsider Problem in Research on Religion and Migration. Bayreuth african studies series, 75 , 79.

29. Miller, D. L., \& Allen, S. (2005). Against all hope: Hope for Africa. Samaritan Strategy Africa Working Group. 